become responsible. Mr. R. Mayorcas has been appointed deputy head of the Steelmaking Division. Mr. E. O. Oldfield has been appointed senior research officer of the Cutler Research Council in succession to $\mathrm{Mr}$. Kington; and $\mathrm{Dr}$. J. Pearson has been appointed consultant to the File Research Council, with Mr. R. H. Hancock continuing as senior investigator. Mr. J. G. Wistreich, who has been head of the Metal Working Laboratory in the Sheffield Laboratories, will become head of the Mechanical Working Division in succession to Mr. W. C. F. Hessenberg, deputy director of the Association, who is relinquishing control of the Division in order to devote the whole of his time to his other duties. Mr. S. S. Carlisle, head of the Association's South Wales Laboratories, becomes deputy head of the Division.

\section{Biochemical Principles in Pharmacy}

Prof. K. Bullock, in the chairman's address on September 3 to the British Pharmaceutical Conference, discussed "Biochemical Principles in Pharmacy". His survey covers enzymology, chemotherapy and disinfection, the relationship between dehydration and life processes and the architecture of living cells. He has achieved a valuable synopsis which presents a balanced account of important principles relevant to his subject and to hypotheses which appear promising. The historical approach and his sequences of discovery and thought, whereby knowledge has grown, are stimulating-the divergencies from one's own sequences can be intriguing. It is an unavoidable penalty to which even excellent surveys must submit that the illustration of a principle may over-simplify the explanation of cause and effect without consideration of every alternative. For example, the phenomena whereby bacteria can utilize a substrate which at first they could not attack, by enzyme induction, is real enough ; but in some instances the phenomena can occur where the enzyme involved is constitutively present but inactive because of coenzyme deficiency. The presence of metal ions-including the monovalent ions-may also affect the activity of some of these enzymes, as the recent symposium of the Biochemical Society shows. Does the reference to the known relationship between the bactericidal properties of the sulphonamides and their antagonism to paraminobenzoic acid exclude other possibilities for sulphonamide action? These comments cannot detract from the value of this extensive and profitable review. When Prof. Bullock dealt with dehydration and life processes, he was in his own chosen field. Does he move almost imperceptively from a position of acquiescence in faith to one of faith in experience?

\section{Engineering Studies in the U.S.S.R.}

A BRITISH engineering delegation is to visit the U.S.S.R. this month to study engineering education and training. The nine members of the group were nominated by the Joint Committee of the Institutions of Civil, Mechanical and Electrical Engineers and the visit will take place under the auspices of the Soviet Relations Committee of the British Council. A return visit to the United Kingdom by a group of Soviet experts is under consideration. The group will leave London by air on September 16, returning probably on September 28. The programme in the U.S.S.R. will include visits to higher technical education establishments in Moscow and Leningrad. The group will be led by Prof. E. Giffen, professor of civil and mechani- cal engineering, Queen Mary College, University of London. Other members are: Mr. W. K. Brasher, secretary of the Institution of Electrical Engineers; Dr. B. N. Cole, Department of Mechanical Engineering, University of Birmingham; Mr. H. E. Dance, H.M. Inspector of Schools (Technical Branch); Dr. H. L. Haslegrave, principal of Loughborough College of Technology; Mr. G. S. C. Lucas, director and chief electrical engineer, British Thomson. Houston Co., Ltd., Rugby ; Mr. P. E. Sleight, head of the Civil Engineering Department, Brighton Technical College; Mr. E. G. Sterland, principal, Apprentices' School, Bristol Aeroplane Company ; Prof. A. S. T. Thomson, Department of Mechanical, Civil and Chemical Engineering, Royal Technical College, Glasgow.

\section{Supply and Training of Teachers for Technical Colleges}

A COMMITTEe, nominated by the chairman of the National Advisory Council on the Training and Supply of Teachers and the chairman of the National Advisory Council on Education for Industry and Commerce, has been set up to advise the Minister of Education urgently upon the recruitment and training of teachers for technical colleges. Its terms of reference are: "To consider in the light of the White Paper on Technical Education (Cmd. 9703) the supply and training of full-time and part-time teachers for technical colleges, and to make recommendations", and it is constituted as follows: Dr. Willis Jackson (chairman), director of research and education, Metropolitan-Vickers Electrical Co., Ltd. ; Councillor R. McKinnon Wood (vice-chairman), London County Council; Dr. F. Briers, principal, Norwich City College and Art School; Sir Hugh Chance, chairman, West Midlands Regional Advisory Council for Technical, Commereial and Art Education; Alderman C. B. Jones, Yorkshire Council for Further Education; Mr. D. R. Mackintosh, Shell Petroleum Co., Ltd.; Miss Anne Shaw, director, The Anne Shaw Organization; Mr. J. G. Docherty, principal, North-Western Polytechnic, London; Mr. A. E. Evans, technical adviser, Association of Teachers in Technical Institutions; Mr. H. Wyn Jones, secretary, Welsh Joint Education Committee; Prof. R. A. C. Oliver, Sarah Fielden professor of education in the University of Manchester; Mr. E. W. Wood. head, Chief Education Officer, Kent; Mr. A. Maclennan, principal, Training College for Technical Teachers, Huddersfield.

\section{Birlec Ltd. Apprentice Training Centre, Birm- ingham}

BrRLec Ltd., furnace manufacturers, of Birmingham, have been training apprentices in their works for some considerable time; but in view of the com. pany's plan for expansion and the need to ensure a continuing supply of trained men of the highest calibre, a new apprentice scheme has been launched and a new Apprentice Training Centre has been built specially. Four full-time instructors have been appointed, two of whom have held lecturing posts in the Birmingham College of Technology and the National Foundry College, Wolverhampton, re. spectively. It is anticipated that the new scheme will cost approximately $£ 20,000$ a year. The new Centre is accommodated in single-story buildings and occupies about $10,000 \mathrm{sq}$. ft. of floor space, with workshop, drawing office and lecture room facilities. 